\title{
ENVIRONMENTAL ASSESSMENT OF PHOTOVOLTAIC TECHNOLOGIES
}

\author{
Anne-Marie Tillman \\ Technical Environmental Planning, Chalmers University of Technology, \\ S-41296 Göteborg, SWEDEN
}

\begin{abstract}
Production of electricity in solar cells enables a flowing energy resource, sunlight, to be brought into the technological system. Although only small adverse environmental effects result from the operation of solar cells, production and sometimes disposal have more environmental impact. The impact is described for a number of types of solar cells, in various applications, and the technology is evaluated from an environmental point of view, as compared with power production fom fossil fuels and nuclear power. A life-cycle perspective is adopted, although the study is not a quantitative life-cycle assessment. Crystalline silicon (c-Si) and amorphous silicon (a-Si) cells, copper-indium-diselenide (CIS) and cadmiumtelluride (CdTe) cells, are considered. $\mathrm{c}$-Si cells require considerable amounts of energy during production. Both CIS and CdTe cells contain cadmium, but CIS to a smaller extent. Indium is a very scarce resource. All the technologies except CdTe involve use of toxic and/or explosive gases during production.

Solar cells are used in consumer products such as pocket calculators. The energy production in this application is marginal. They may consitute an environmental problem if they contain cadmium or are used in connection with cadmium containing batteries. Stand-alone systems often require batteries, which contain heavy metals. They may contribute to electricity generation to some extent. They may have a positive influence on aesthetic natural values through reducing the need for power transfer to single, remote power consumers. Large scale electricity production in grid-connected systems are possible in a longer time perspective, and thus the assessment has a larger degree of uncertainty. The systems could make a large contribution to electricity production. However, over a certain production capacity, this requires energy storage, e.g. in water reservoirs or as hydrogen. Large scale electricity production in solar celis is assessed, from an environmental point of view, to be a better alternative than nuclear or fossil fuel based power generation.
\end{abstract}

\section{INTRODUCTION}

Production of electricity in solar cells enables a flowing energy resource, sunlight, to be brought into the technological system. Unlike combustion of fossil fuels, the operation of solar cells causes no emissions of greenhouse gases or acidifying gases to the atmosphere. Neither does it generate radioactive waste, as does nucler power generation. Although the adverse environmental effects caused by the operation of solar cells are small, production and sometimes disposal do have an environmental impact. This impact is described for a number of types of solar cells, in various applications, and the technology is evaluated from an environmental point of view, as 
compared with power production from fossil fuels and nuclear power.

The conceptual framework used for the assessment was developed by Svensson et.al. (1991) (c.f. Figure 1). Technological systems cause environmental loadings in terms of resource use (aquisition of raw materials, land use, etc.) and emissions of pollutants and waste to air, water or soil. Technological systems are controlled by man, and may be manipulated. Nature transforms the loadings into changes interpreted as environmental effects. This transformation cannot be influenced by human activities. The environmental consequences are the final valuation and the weighing of the beneficial and adverse effects of a technology.

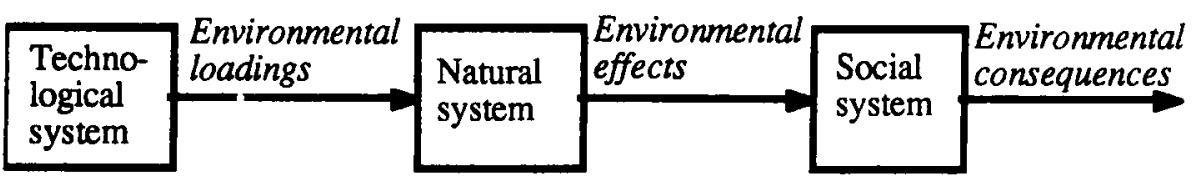

Figure 1. Basic concepts for systemic analysis of environmental consequences of activities in the technological system.

A life-cycle perspective is adopted in this study, i.e. production, use and waste management of solar cells are considered. The study is, however, not a quantitative life-cycle assessment, but a qualititive assessment of potential environmental effects associated with the life-cycles of solar cells. Not all processes are included, for example transportation is omitted. Neither installment in power production plants nor production and operation of equipment for power conversion, e.g. from direct current to alternating current, are included.

Only the types of solar cells that are commercially available, i.e. crystalline silicon cells and amorphous silicon cells, or are close to introduction on the market, i.e. copper-indium-diselenide (CIS) and cadmium-telluride cells (CdTe), are described. A Swedish perspective is adopted. This has no influence on the environmental consequences of production, but land use is strongly dependent on solar radiation intensity, which differs at different latitudes. The conclusions in this respect will be valid for other areas with similar solar radiation. The high ratio of diffuse solar radiation makes concentrating photovoltaic arrays unsuitable for use in Sweden. Thus, these types of solar cells are not covered by this study.

\section{TECHNICAL DESCRIPTION AND ENVIRONMENTAL LOADING CAUSED BY THE LIFE-CYCLE OF SOLAR CELLS \\ Crystalline silicon solar cells}

Crystalline silicon (c-Si) solar cells are the oldest type of photovoltaic devices, with approximately $70 \%$ of the world market (Photovoltatic insider's report 1992). Efficiency in commercially available modules is $12-15 \%$. The technology is well established and the lifetime of modules lies in the range of 30 years (Treble 1991a).

Crystalline silicon cells are produced from silicon dioxide, which is widely 
available in quartzite or high-grade quartz sand. Metallurgical grade silicon is produced through reduction with carbon in arc furnaces. The silicon is further refined to semiconductor grade through conversion with hydrogen chloride to trichlorosilane, which is distilled. The purified trichlorosilane is then reacted with hydrogen to produce semiconductor grade silicon and hydrogen chloride. The process is highly energy demanding and has a relatively low yield of purified silicon. Processes for purifying silicon, with lower energy demand, are under development (Zweibel 1990).

A semiconductor, such as silicon, can be made to conduct electricity through the addition of a small amount of an impurity (dopant). The resulting material can be of two types, p-type in which the dopant has fewer valence electrons than the semiconductor, or n-type in which the dopant has more valence electrons than the semiconductor. The ability of photovoltaics to produce electricity from light is dependent on the junction between layers of different types.

Crystals suitable for solar cells can be produced in a number of ways. One commonly-used method is the Czochralski process, in which a single crystal ingot is produced from molten silicon. The ingot is sawn into wafers, a process that results in losses of approximately $50 \%$ of the material. The silicon wafers are usually of p-type through the introduction of boron in the molten silicon. A common method for producing an n-type layer is through diffusion from a gas phase consisting of phosphorus oxychloride ( $\mathrm{POCl}_{3}$ ) (Treble 1991b).

To complete the cell, metal contacts are added to both sides of the cell. Metal contacts are deposited from evaporated metals, in grid lines on the top surface and covering the whole back surface. Metals such as titanium, silver and palladium are used. The top surface is covered by an anti-reflection layer (c.f. figure 2). The cells are electrically connected and mounted in modules, well incapsulated under glass.

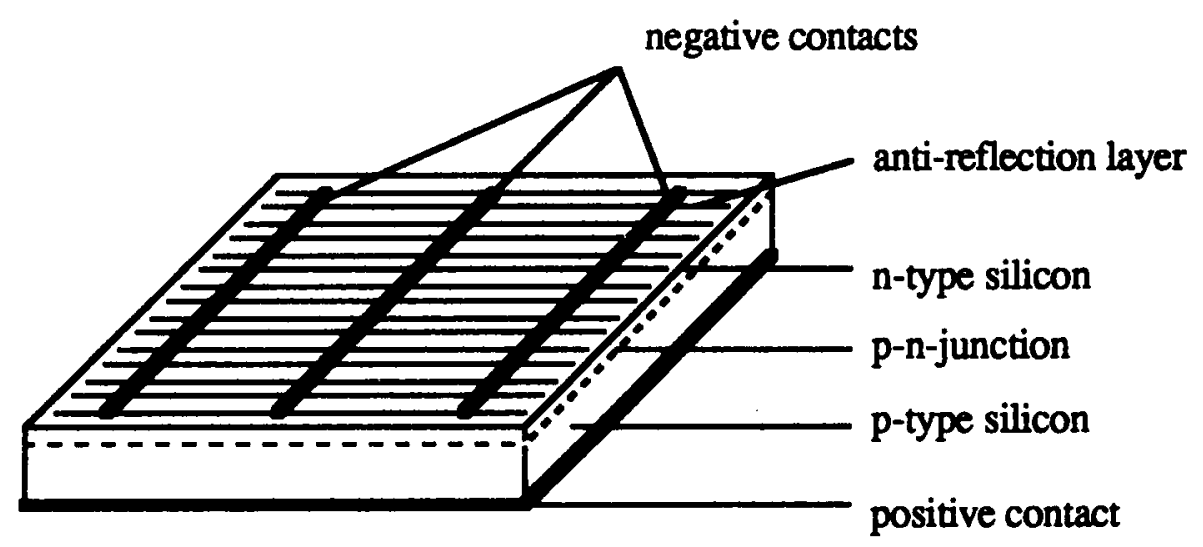

Figure 2. Crystalline silicon solar cell. (After Treble 1991b). 
The environmental loadings caused by production, use and disposal of crystalline silicon solar cells are mainly caused by the energy use in the production process. Hagedorn (1989) reports a six year energy payback time for present-day production of crystalline silicon modules, increased to seven years if the production of electrical equipment and installment in a power production plant are included. He estimates that the energy payback time for power production plants may be reduced to approximately four years, if known technology for enhanced production efficiency is realized. A much more optimistic veiw is taken in a study by Palz and Zibetta (1991), reporting an energy paypack time of 2.1 years for polycrystalline modules. Differences in system boundaries and technological levels used in the two studies account for a large part of the difference in result. To calculate the energy payback time, Hagedom (1989) uses the electrical power produced by the solar cells divided by the consumption of primary energy for producing them. Palz and Zibetta (1991) use the energy consumption as measured by the plants producing the photovoltaics to calculate the same entity. They also use a much lower estimation of the energy requirements for production of the feed-stock silicon.

Crystalline silicon solar cells are made from abundantly available raw materials, quartzite and quartz sand. The only environmental problem they can be anticipated to cause when they are disposed of as waste is that they use land area. In addition, some of the contact metals used, such as silver, are toxic.

Some of the chemicals used in the process are potential risks to workers and persons in the vicinity of production facilities. Hydrogen chloride and phosphorus oxychloride $\left(\mathrm{POCl}_{3}\right)$ are corrosive acids. Chlorosilanes, used in the refining of silicon, have a risk of exploslon.

\section{Amorphous silicon solar cells}

Solar cells based on amorphous silicon (a-Si) have been commercially available since 1980. They are used primarily in consumer products, such as calculators and garden outdoor lights. Efficiency in commercially available modules is 5-7\% (Garner 1990). a-Si cells have a light induced loss of efficiency during their first months of use. This initial loss of efficiency can be compensated for in the design of a-Si systems. However, some uncertainty still remains about the long-term outdoor stability of a-Si modules (Zweibel 1990).

To make a-Si photovoltaic devices, thin films are deposited on a substrate, usually glass. The first layer is a transparent, conductive layer of fluorine doped tin oxide. Amorphous silicon is deposited from a gas phase consisting of silane $\left(\mathrm{SiH}_{4}\right)$. Dopants are added to the gas as phosphine $\left(\mathrm{PH}_{3}\right)$ and diborane $\left(\mathrm{B}_{2} \mathrm{H}_{6}\right)$. Finally, a conductive film of silver or aluminum is deposited (Zweibel 1990). A thin film module is a less complicated construction than a c-Si module. The layers are already deposited on glass, and only have to be incapsulated in one direction.

As for c-Si solar cells, a-Si solar cells are made from widely available raw 
materials. They contain no toxic substances, except possibly in contact layers.

If accidentally released, the gases used in the production present a risk to workers and persons in the vicinity of production facilities. Silane, phosphine, and diborane self-ignite on contact with air. Phosphine and diborane are also toxic.

The energy needed for production of a-Si solar cells is considerably lower than is needed to produce c-Si cells. Hagedorn (1989) reports an energy payback time of approximately three years for present-day production of a-Si solar cells, which is increased to 4.7 years if the production of electrical equipment and installment in a power production plant are included. He estimates that the energy pay-back time for power production plants may be reduced to approximately 2.5 years, if known technology for enhanced production efficiency is realized. Palz and Zibetta (1991), on the other hand, report a 1.3 years energy payback time for a-Si modules.

\section{Copper-indium-diselenide (CIS) and cadmium-telluride (CdTe)}

The copper-indium-diselenide thin film cell is a more recent development. Efficiencies of 14\% have been obtained for cells (Sigurd 1991) and 10\% for modules. The stability of the cells has been proven in six months of tests by an independent laboratory (Zweibel 1990). However, the stability has not been proven in long term use, as is the case with c-Si cells.

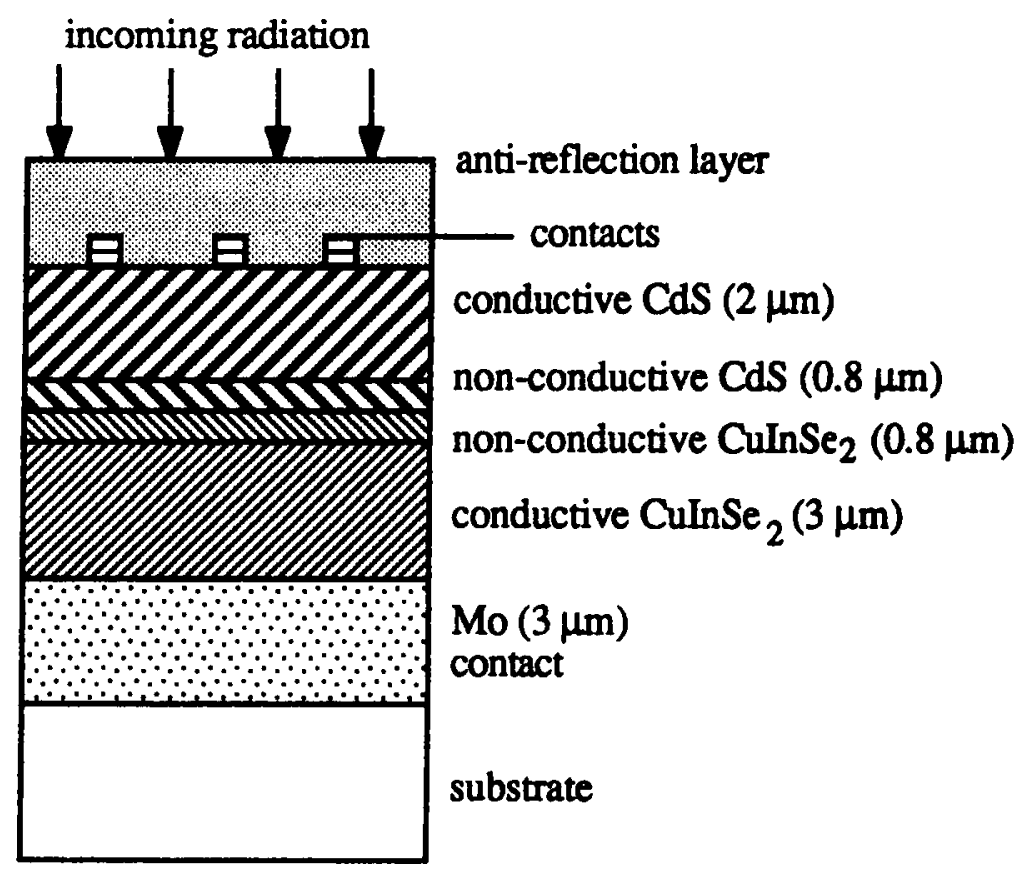

Figure 3. Example of copper-indium-dieselenide (CIS) solar cell. (After Ullal et.al. 1990) 


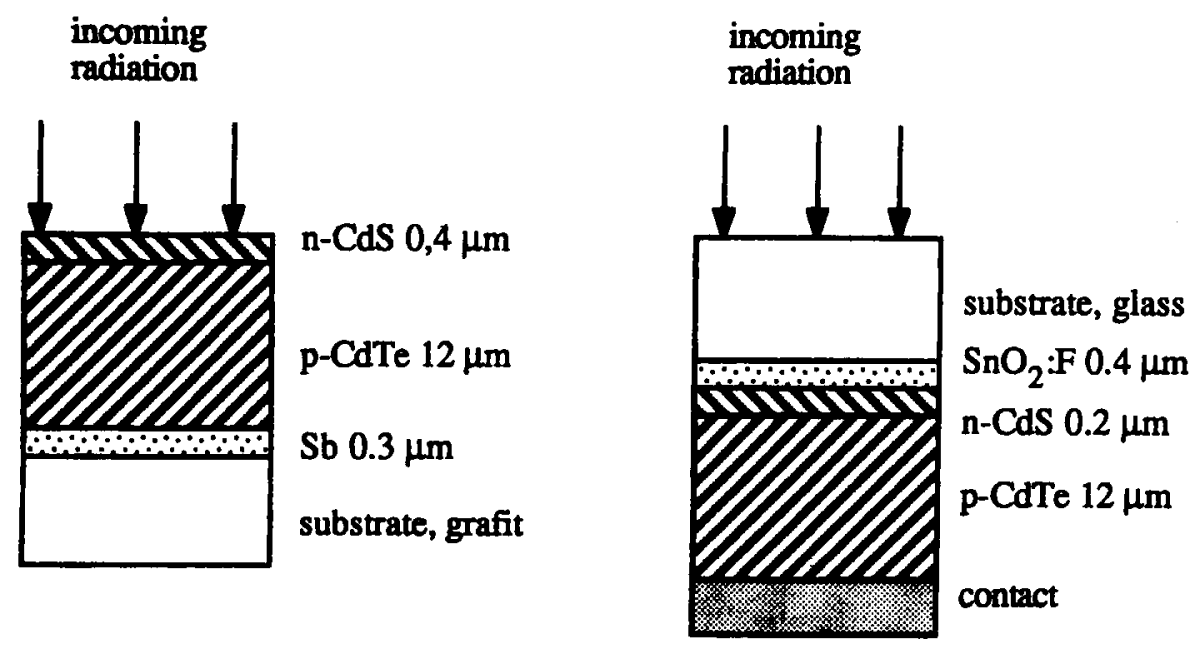

Figure 4. Examples of cadmium-telluride (CdTe) solar cells. (After Hill 1991)

Figure 3 shows an example of the structure of a CIS-cell. The films can be deposited using a number of methods. In early techniques the metals copper, indium and selenium were evaporated from heated metal sources and allowed to condense on a substrate. Cadmium-sulphide (CdS) was also evaporated from a CdS-source. In more recent developments, metallic indium and copper are deposited from metal sources, whereupon selenium is deposited from a gas phase consisting of hydrogen selenide $\left(\mathrm{SeH}_{2}\right) . \mathrm{CdS}$ may be deposited as very thin films from a solution (Zweibel 1990).

Another type of thin film cell is based on cadmium telluride. They have efficiencies close to those of CIS cells (Zweibel 1990). An example of the structure of CdTe cells is shown in figure 4. There are a number of techniques for depositing the films, including electro-deposition, evaporation, spraying and screen-printing.

The main environmental concerns in the life-cycles of CIS and CdTe solar cells are related to the use of the heavy metal cadmium, and the use of scarce resources, particurlarly indium in CIS cells, and use of the toxic gas hydrogen selenide for CIS cells.

Particularly indium, but also tellurium, are resources of limited availability, as shown in table 1. Production capacity is not critical, production can always he increased with increased demand. Reserves are the amounts estimated to be available from known sources at present price and technology. They are rarely equivalent to more than 10-20 years of extraction for any material. Resources are the quantities estimated to be available in unexplored depots, also at present price and technology.

Both CIS and CdTe solar cells contain cadmium. The amount of cadmium in CIS cells is lower than in CdTe cells. It is also not a physical requirement for the function oi CIS cells that they contain cadmium. 
Table 1: Mass of rare elements required for solar cells with $1 \mathrm{GW}_{\mathbf{p}}{ }^{1}$ with $10 \%$ efficiency, assuming $\mathrm{l} \mu \mathrm{m}$ thickness. Estimated annual production capacity, world reserves and world resources. (Adopted after Hill 1991.)

$\begin{array}{lrrrrr}\text { Cell type } & \begin{array}{c}\text { Rare } \\ \text { element }\end{array} & \begin{array}{c}\text { Tonnes/GW } \\ \text { at } 1 \mu \mathrm{m}\end{array} & \begin{array}{c}\text { Production } \\ \text { tonnes/Year }\end{array} & \begin{array}{r}\text { Reserves } \\ 10^{3} \text { tonnes }\end{array} & \begin{array}{r}\text { Resources } \\ 10^{3} \text { tonnes }\end{array} \\ \text { CIS } & \mathrm{Cd} & 67 & 20.000 & 750 & 18.000 \\ & \mathrm{In} & 25 & 65 & 2 & 2 \\ \mathrm{Se} & 23 & 23 & 170 & 460 \\ \mathrm{CdTe} & \mathrm{Cd} & 108 & 20.000 & 750 & 18.000 \\ & \mathrm{Te} & 33 & 406 & 40 & 110\end{array}$

${ }^{1} W_{p}$ is the unit of the peak effect, which is the electric effect delivered by a photovoltaic device under standardized temperature, light intensity and spectral composition of the light.

Production of cadmium-containing solar cells causes risks to workers. In some respects, cadmium is a more easily controlled working environmental problem than explosive and toxic gases, which have an acute effect. Workers' exposure to cadmium may be monitored, as may the concentration of cadmium in the body.

The outdoor environment around production facilities may also be exposed to cadmium, either under normal production circumstances or through accidents such as leakage or fire. Moreover, if the material is not fully utilized, hazardous waste is generated. This applies to all production activities in the life-cycle where cadmium is handled, including mining, metal refinement and solar cell production.

During use there is a risk of fire in photovoltaic systems. The risk of health effects from cadmium, arsenic and selenium spread during fire accidents in photovoltaic installations containing these elements has been studied by Moskowitz and Fthenakis (1990). They concluded that the risk of health effects from fires in small, residential installations $\left.\left(5 \mathrm{~kW}_{\mathrm{p}}\right)^{\mathrm{l}}\right)$ is small. For larger installations $\left(100 \mathrm{~kW}_{\mathrm{p}}\right.$ on roofs of commercial buildings and $500 \mathrm{~kW}_{\mathrm{p}}$ mounted on the ground), simple mitigation strategies were recommended, such as alerting all residents within 1-2 km of a fire to remain in their homes with closed doors and windows. The risk was assessed to be greater from installations on commercial buildings, than from larger ground-mounted installations, owing to the higher probability of a fire and the larger amounts of combustible materials.

Spent photovoltaics containing cadmium constitute a risk for diffuse dispersion of cadmium. Moskowitz and Fthenakis (1991) report a pilot study where CIS and CdTe modules were leached in a standardized procedure. The cadmium concentration in the leachate from the CdTe module was 8-10 times the limit set by the U.S. Environmental Protection Agency. The concentration in the leachate from the CIS module was only $15 \%$ of the limit. In the reported pilot study only one sample of each type was tested.

${ }^{1} W_{p}$ is the unit of the peak effect, which is the electric effect delivered by a photovoltaic device under standardized temperature, light intensity and spectral composition of the light. 
If the results are correct for a larger selection of modules they indicate that spent CdTe modules would be classified as hazardous waste, according to U.S. regulations, and would therefore require controlled disposal conditions.

Recycling of the elements in solar cells would decrease the total environmental impact of the cells, especially with respect to indium, which is an extremely scarce resource, and cadmium, which is a known toxin.

The most important types of environmental loadings associated with the life-cycles of the various kinds of solar cells are summarized in table 2.

Table 2. Summary of the main types of environmental loadings associated with the lifecycles of various types of solar cells.

$\begin{array}{lcccl}\text { Cell type } & \begin{array}{c}\text { Energy demand } \\ \text { during production }\end{array} & \text { Cadmium } & \begin{array}{c}\text { Use of scarce } \\ \text { resources }\end{array} & \begin{array}{l}\text { Toxic/explosive } \\ \text { gases }\end{array} \\ \text { c-Si } & \text { high } & - & - & \mathrm{SiHCl}_{3} \\ \text { a-Si } & \text { less } & - & - & \mathrm{SiH}_{4}, \mathrm{~B}_{2} \mathrm{H}_{6}, \mathrm{PH}_{3} \\ \text { CIS } & \text { less } & \text { yes } & \text { indium } & \mathrm{SeH}_{2} \\ \text { CdTe } & \text { less } & \text { yes } & - & -\end{array}$

${ }^{1}$ Less cadmium is used in CIS cells than in CdTe cells.

\section{ENVIRONMENTAL EFFECTS}

Environmental effects associated with the life-cycles of solar cells are to a large extent risks of health effects owing to use of explosive and/or toxic gases and use of heavy metals. Cadmium is of special concern, although several of the other elements used have toxic effects. Below, environmental effects of the various substances if released to the environment are summarized. It has not been possible to estimate the risk of release of the substances.

\section{Elements}

\section{Cadmium}

Elements such as cadmium are not degradable and are consequently characterized by a long environmental persistence. Cadmium is toxic to all living organisms. It is taken up by plants more easily than other metals. Plants may have cadmium contents similar to those of the soil. Cadimium may also be taken up from the atmosphere. Effects in plants range from decreased productivity, reduced photosynthesis and transpiration and changed enzymatic activities (Merian 1990).

High cadmium concentrations in soil, compost or sewege sludge damage microorganisms necessary for the decomposition of organic matter. Nitrogen fixation may also be reduced (Merian 1990).

As a detrimental metal (Morrison 1994), cadmium has ecological effects at any concentration above the background level in aquatic environments. Ecological 
responses such as changes in community structure and loss of reproductive capacity can be anticipated at concentrations below the $\mu \mathrm{g} / \mathrm{l}$ level.

Doses causing acute effects in terrestrial animals are uncommon. Acute effects in humans may be caused by accidential exposure, e.g. in working environments. Both inhalation and ingestion have effects, which, depending on dose, can range from pulmonary or abdominal irritation, respectively, to death.

Acute intoxication is, however, not the main concern in relation to cadmium, but rather chronic effects owing to the element's tendency to accumulate in the body. The biological half-time in humans is approximately 30 years (Robarbs and Worsfold 1991). Mammals are affected in the same way as humans. The main human exposure route is via food, although absorption via the lungs can contribute significantly to the total cadmium intake of individuals living near cadmium sources, or smokers. Cadmium is accumulated in the kidney cortex. Chronic cadmium intoxication is known from Japan, where it caused renal dysfunction and structural changes in bones (Merian 1990). Various types of lung diseases, including lung cancer, have been found in workers chronically exposed to cadmium dust and fumes (Moskowitz and Fthenakis 1991 ).

\section{Selenium}

Selenium is an essential element for mammals and birds, although it is toxic in overly high doses. Drainage of irrigation water from selenium rich agricultural soils have caused damage to bird wildlife in California. Intoxication of livestock that graze on plants growing on soils rich in selenium, is a well-known condition. Animals may also be subject to selenium deficiency.

Chronic intoxication of humans is not a common condition, but has occurred in China, caused by contamination of agricultural soil with selenium. The most common effects were loss of hair and fingernails, although disorders of the skin, nervous system and teeth have also occurred. Acute intoxication has effects such as nausea, vomiting and diarrhea (Harte et.al. 1991 ).

\section{Copper}

Copper is also an essential element, both for plants and animals. It has an important role in nitrogen fixation and photosynthesis. Copper is taken up by plants, although an increase in the copper content of soil is far from proportional to an increase in copper content in crops. High copper content in soils reduce root formation and plant growth. Copper affects nitrifcation processes, both in soil and in phytoplankton. Photosynthesis in algae is also reduced by elevated copper concentrations. The toxicity of copper in the aquatic environment is highly dependent on its speciation.

Copper deficiency has not been observed in adult humans. Acute intoxication of humans results in nausea, vomiting and diarrhea. Copper fumes may cause metal fever. Chronic copper intoxication is very uncommon (Laveskog et.al. 1976). 


\section{Tellurium and indium}

Tellurium and indium are rare elements with no known biological function and are therefore detrimental even at very low concentration. Very little data is available on their ecotoxicological properties. Health effects from acute exposure are summarized below:

Indium may be absorbed in the lungs and may cause damage to the respiratory system, kidneys and liver (Sittig 1993). Indium taken orally is not very toxic (Laveskog et.al. 1976). Ingestion of tellurium has toxic effects. In the body it is converted to dimethyl telluride, causing a garlic-like odour to the breath and sweat. Depending on dose, effects range from headache, metallic taste, nausea, and respiratory arrest to death (Lewis 1992).

\section{Hazardous gases}

A number of hazardous gases are used in the production of solar cells, as summarized in table 3. The gases present risks, both of intoxication and fire and explosions, to workers and persons in the vicinity of production facilities. Since the gases are all highly reactive, it is not probable that they persist long enough after release to cause environmental effects.

Table 3: Properties of hazardous gases used in the production of solar cells. Compiled from Lewis (1992) and Moskowitz et.al. (1986-87)

\begin{tabular}{|c|c|c|c|}
\hline Cell & Gas & Fire hazard & Toxicity \\
\hline \multirow[t]{2}{*}{$\mathrm{c}-\mathrm{Si}$} & $\begin{array}{l}\mathrm{SiHCl}_{3} \\
\text { trichloro- } \\
\text { silane }\end{array}$ & $\begin{array}{l}\text { Severe fire hazard } \\
\text { when exposed } \\
\text { to heat, flame or air. }\end{array}$ & $\begin{array}{l}\text { Moderately toxic after } \\
\text { ingestion and inhalation. }\end{array}$ \\
\hline & $\begin{array}{l}\mathrm{POCl}_{3} \\
\text { phosphorus } \\
\text { oxychloride }\end{array}$ & $\begin{array}{l}\text { Potentially explosive } \\
\text { reaction with water. }\end{array}$ & $\begin{array}{l}\text { Toxic after ingestion and } \\
\text { inhalation. }\end{array}$ \\
\hline \multirow[t]{3}{*}{$\mathbf{a}-\mathbf{S i}$} & $\begin{array}{l}\mathrm{SiH}_{4} \\
\text { silane }\end{array}$ & $\begin{array}{l}\text { Easily ignited in air. } \\
\text { May self-explode. }\end{array}$ & Mildly toxic after inhalation. \\
\hline & $\begin{array}{l}\mathrm{PH}_{3} \\
\text { phosphine }\end{array}$ & $\begin{array}{l}\text { Spontaneous ignition in } \\
\text { air. Severe fire hazard } \\
\text { by spontaneous } \\
\text { chemical reaction. }\end{array}$ & Very toxic. \\
\hline & $\begin{array}{l}\mathrm{B}_{2} \mathrm{H}_{6} \\
\text { diborane }\end{array}$ & $\begin{array}{l}\text { Reacts violently with air. } \\
\text { Reacts with water to give } \\
\text { explosive hydrogen. }\end{array}$ & Highly toxic. \\
\hline CIS & $\begin{array}{l}\mathrm{SeH}_{2} \\
\text { hydrogen } \\
\text { selenide }\end{array}$ & $\begin{array}{l}\text { Dangerous fire hazard } \\
\text { when exposed to heat } \\
\text { or flame. Forms explosive } \\
\text { mixtures with air. }\end{array}$ & Extremely toxic. \\
\hline
\end{tabular}




\section{APPLICATIONS}

When assessing the environmental consequenses of photovoltaic technology, the whole system, including storage systems when these are part of the system, should be considered. Applications of solar cells can be divided into (Sigurd 1991):

- Consumer products, such as pocket calculators and garden lights. Storage of the collected solar energy in batteries is often a prerequisite for this application.

- $\quad$ Stand-alone systems, such as cabins, boats, water pumping systems, etc., not connected to the grid. Battery storage is a prerequisite for many of these applications.

Grid-connected systems. Surplus energy is delivered to the grid. When the local load exceeds the production of the solar cells, the grid delivers the difference. The grid in itself, with its regulating capacity, may act as a storage facility, up to a certain capacity for intermittent power generation. At higher capacities, special storage capacity is needed.

\section{Energy storage}

For many applications of solar cells, energy storage is a necessity. For small systems, electricity is stored in batteries. For photovoltaic power generation on a larger scale, other methods must be used. As mentioned above, the electrical grid, with its regulating capacity, may act as a storage up to a certain photovoltaic production capacity. Utilisation of the grid's regulating capacity means that energy is stored as fuel or in hydropower reservoirs. Should this capacity be exceeded, other forms of energy storage must be used. A number of possibilities are described below.

Energy may be stored in water reservoirs. Existing Swedish hydropower installations have an inherent storage capacity for intermittently produced electricity, e.g. wind or solar generated electricity, of 3.5 to 7 TWh (Engström 1984). Hydropower in Sweden produces approximately $65 \mathrm{TWh}$ annually, corresponding to almost $50 \%$ of the electrical power produced (Energifakta 1991). Should the existing storage capacity be exceeded, separate reservoirs may be built and water pumped uphill for storage. The main concern would be to find suitable sites for such installations.

It is possible to store compressed air in large underground caverns, e.g. deep rock caverns, empty salt caverns or aquifers. The air, supplemented with burning natural gas, can be used to operate a generator. The natural gas could possibly be replaced with PV-generated hydrogen (Zweibel 1990).

Water may be electrolyzed to hydrogen and oxygen using the direct current produced in solar cells, and the hydrogen can then be stored and used in several ways. 
Storage possibilites include (Carpetis 1988):

- Underground storage of compressed gaseous hydrogen in caverns and aquifers.

- $\quad$ Above ground pressure gas storage.

- $\quad$ Liquid hydrogen storage at approximately $20 \mathrm{~K}$.

- Metal hydride storage.

- Cryo-adsorbing storage at $60-100 \mathrm{~K}$ in a container filled with a porous material, e.g. active carbon.

Hydrogen may be transported in a number of ways, according to Carpetis (1988). There are pipeline systems for distribution of gaseous hydrogen, e.g. a $210 \mathrm{~km}$ long system in Germany, connecting 18 plants. Hydrogen may also be distributed as pressurized gas by rail and road, which is expensive. Liquid hydrogen may be transported in cryogenic containers, which is suitable, for example, for sea transport. This technology is not available at present, but may possibly be developed from existing technology for liquid natural gas transportation.

There are a number of possible uses for hydrogen (Peschka 1988, Zweibel 1990). It may be used as a fuel for heat production. Large scale hydrogen combustion is stateof-the-art. There are no suitable burners for small scale combustion, although town gas may contain up to $60 \%$ hydrogen. Hydrogen may be used as a fuel in gas turbines producing electricity. It may even be possible to combust hydrogen with the oxygen produced in the electrolysis process in gas turbines. However, this requires further technical development of gas turbines so that they can withstand very high combustion temperatures. Electricity may also be produced from hydrogen and oxygen in fuel cells. Hydrogen may be used as a vehicle fuel.

\section{ENVIRONMENTAL LOADINGS AND EFFECTS IN RELATION TO DIFFERENT APPLICATIONS}

\section{Land use}

The received solar radiation in Sweden averages approximately $1000 \mathrm{kWh} / \mathrm{year}, \mathrm{m}^{2}$ (Engström 1984). Assuming 12\% efficiency and 50\% of the surface of a solar cell field covered by active photovoltaic devices, $16 \mathrm{~km}^{2}$ would be needed to produce 1 $\mathrm{TWh} / \mathrm{year}$. In countries with higher solar radiation intensity, the required surface is reduced accordingly. To produce the same amount of electricity as the Swedish nuclear power plants (approximately $70 \mathrm{TWh} / \mathrm{year}$ out of totally $140 \mathrm{TWh} / \mathrm{year}$ (Energifakta 1991)) an area of $33 \times 33 \mathrm{~km}$ would be needed. It is not possible to have so much production without energy storage, which would require additional land areas.

A study comparing photovoltaics with nuclear and coal generated power (DOE 1989) concluded that the area requirements for electricity produced in a simulated photovoltaic plant, situated in California, would be slightly less than those of coal derived electricity, owing to the high area demands of coal strip mining. 
Solar cells may be mounted on buildings and thus require no additional land area. The maximum potential for electricity production in roof mounted photovoltaics in Sweden has been estimated at $30 \mathrm{TWh} /$ year (Engström 1984). However, there may be competition for the available roof area from thermal solar collectors.

\section{Storage in water reservoirs}

Environmental loadings increase only marginally if the surplus storage capacity in existing reservoirs is used to store electricity generated by solar cells. Installation of reservoirs beyond existing capacity have the same type of environmental effects as hydropower, including flooding of large land areas, which are irreversibly changed, and eroded shores. The area seasonally flooded in Swedish hydropower installations is in the order of magnitude of $100 \mathrm{~km}^{2} / \mathrm{TWh}$, year (Svensson et.al. 1991).

\section{Storage in batteries}

Solar powered consumer products and stand-alone systems are normally connected to batteries. These may be responsible for a considerable part of the system's environmental loadings, since they often contain heavy metals. The most common types of batteries are lead acid batteries and nickel cadmium (NiCd) batteries, although rechargeable batteries free from heavy metals are now being introduced on the market.

\section{Sorage and use of hydrogen}

Storage, distribution and use of hydrogen constitute an explosion risk. Safety aspects of hydrogen as an energy carrier have been evaluated by Fischer and Eichert (1988). Hydrogen has been used safely in large scale industrial applications for decades. Even with a sharp increase in the industrial use of hydrogen, no new safety problems are expected. However, extended use of hydrogen as an energy carrier, in new applications, where non-professionals will be handling the gas, raises new safety issues.

Hydrogen has a very wide ignition range. However, in realistic accident situations, the lower ignition limit is of primary importance. The lower ignition limit of hydrogen is very similiar to that of natural gas. According to Fischer and Eichert (1988), the very low minimum ignition energy for hydrogen is insignificant, since even weak ignition sources release more energy than is necessary to ignite natural gas, for example. Fischer and Eichert (1988) assess that traffic accidents with liquid hydrogen fuel involved present notably lower risk potential to drivers, passengers and pedestrians as compared with accidents with gasoline involved. This is due to the very short evaporation time of hydrogen as well as its quick burning time and the very fast distribution and dilution of evaporating hydrogen in the open. Complete proof has yet to be demonstrated, however. A major safety problem is the risk of self-acceleration of combustion processes in totally or partially confined rooms, due to hydrogen' s high 
liability to detonation.

Combustion of hydrogen in a:r. for example in vehicle motors, results in the formation of nitrogen oxides. Nitrogen oxides contribute to several environmental problems, such as acidification, eutrophication and damage to forests and crops through formation of photo-oxidants. Combustion in oxygen, and oxidation in fuels cells, give water as the only reaction product.

\section{ENVIRONMENTAL CONSEQUENCES}

It is suitable to make separate assessments of the environmental consequences of solar cells for the various applications consumer products, stand-alone systems, and gridconnected systems. The time horizons of the different assessments vary. Consumer products are already commercial, as are stand-alone systems in many countries. Gridconnected systems on a large scale will, however, only be possible on a longer time perspective.

\section{Consumer products}

Solar cell powered consumer products usually have silicon cells, although there are also some products with CdTe-cells. Batteries are often a prerequisite for this application. Consumer products and stand-alone systems are an important basis for the solar cell industry and thus for the further development of the technology. Solar cells in consumer products contribute only marginally to energy production.

Use of cadmium in consumer products, in batteries or photovoltaics, result in diffuse dispersion of cadmium. The products will eventually end up in municipal waste treatment, cadmium being dispersed either with the flue gases from incineration plants or with leachate from landfills. Use of cadmium in consumer products is highly unsuitable for environmental reasons. For some products, their largest environmental impact is due to the batteries' heavy metal content. From an environmental perspective, a replacement of $\mathrm{NiCd}$ batteries with rechargable batteries free from heavy metals is highly desirable.

\section{Stand-alone systems}

Stand-alone systems are in many cases dependent on batteries. They compete with enlargment of the grid or with other stand-alone power generation, such as diesel fuelled power generation.

Stand-alone solar cell systems may contribute to energy production to a certain extent. They may have a positive influence on aesthetic natural values through reducing the need for power transfer to single, remote power consumers, e.g. summer houses or emergency radio stations. Conducting lines may cause severe damage to aesthetic values in sensitive areas. They also decrease wood production if they are drawn through productive forest.

Stand-alone solar cell systems are assessed as being better from an envronmental 
point of view than diesel fuelled power generation.

Burning of fossil fuels, such as diesel fuel, reduces the amount of a non-renewable resource and contributes to the acidification through emission of sulphur dioxide and nitrogen oxides. The nitrogen oxides also contribute to eutrophication and formation of photo-oxidants. In addition, the carbon dioxide formed from combustion of fossil fuels contributes to global climate change.

\section{Grid-connected systems}

Existing grid-connected systems, as well as those realized in a relatively near future, are based on silicon technology and operate within the existing regulating capacity of the grid. In a longer time perspective, larger capacities for grid-connected photovoltaic power generation may be built up. Assessment of the environmental consequenses of such a

Table 4: Assessment of environmental consequences of electricity production in solar cells, as compared with electricity production from fossil fuels and nuclear energy.

\begin{tabular}{|c|c|c|c|}
\hline & Solar cells & Fossil fuels & $\begin{array}{l}\text { Nuclear } \\
\text { energy }\end{array}$ \\
\hline Use of scarce resources & Indium & Oil, natural gas & Uranium \\
\hline Global climate change & No & Yes & No \\
\hline Acidification & No & Yes & No \\
\hline Eutrophication & No & Yes & No \\
\hline Effects of photo-oxidants & No & Yes & No \\
\hline Risks during production & $\begin{array}{l}\text { Toxic and explosive } \\
\text { gases, } \mathrm{Cd}\end{array}$ & $\begin{array}{l}\text { Oil emissions at sea, } \\
\text { explosions and fire in } \\
\text { plants, mining accidents }\end{array}$ & $\begin{array}{l}\text { Risk of emissions } \\
\text { of radioactive } \\
\text { material during } \\
\text { uranium mining and } \\
\text { fuel production }\end{array}$ \\
\hline Risks during operation & Small & Small & $\begin{array}{l}\text { Small probability, } \\
\text { severe } \\
\text { consequences }\end{array}$ \\
\hline Hazardous waste & $\begin{array}{l}\text { Cd-containing } \\
\text { waste }\end{array}$ & $\begin{array}{l}\text { Metals in ashes and } \\
\text { products from flue gas } \\
\text { purification }\end{array}$ & Radio-active waste \\
\hline $\begin{array}{l}\text { Coupling to nuclear } \\
\text { weapons }\end{array}$ & No & No & Yes \\
\hline Energy storage & $\begin{array}{l}\text { Necessary over a } \\
\text { certain capacity, } \\
\text { will cause environ- } \\
\text { mental loadings } \\
\text { or risks of explosion }\end{array}$ & $\begin{array}{l}\text { As fuel, marginal } \\
\text { environmental loadings }\end{array}$ & $\begin{array}{l}\text { As fuel, marginal } \\
\text { environmental } \\
\text { loadings }\end{array}$ \\
\hline
\end{tabular}


development has a larger degree of uncertainty, since it is still unclear what type of solar cells will eventually, if ever, be competitive and what type of storage will then be realized. A comparison is made between electricity production in solar cells, from fossil fuels and from nuclear power. Additionally, hydrogen storage and use are discussed.

Grid-connected systems could make a large contribution to electricity production. Silicon based, grid-connected systems operating within the regulating capacity of the grid are assessed to be better, from an environmental point of view, than electricity production based on fossil fuels and nuclear power. Also at production capacities above the grid's regulating capacity, and if other photovoltaic technologies should be used, solar cells can become the better option. The assessments are based on considerations summarized in table 4 , which has been simplified, out of necessity. In a life-cycle perspective neither nuclear nor photovoltaic power is free from the emissions caused by combustion of fossil fuels, since fossil fuels are used in mining, refining and transport of both uranium and silicon. However, the emissions are small compared to those from electricity production based on fossil fuels.

All three technologies depend on non-renewable resources, some of which are scarce. Uranium, oil and natural gas are available only in limited quantities, whereas coal is more abundant (Energifakta 1991). Photovoltaics based on silicon are made from abundantly available raw materials, whereas other technologies depend on rare elements, of which particularly indium is very scarce (Hill 1991).

In contrast to photovoltaic and nuclear electricity production, combustion of fossil fuels causes emissions to the air of e.g. carbon dioxide, sulphur dioxide and nitrogen oxides, substances which contribute to a number of large scale environmental effects. Among these are global climate change, acidification, eutrophication and damage to forrests and crops through photo-oxidants. The emissions also have health effects.

All three technologies involve risks of emissions and accidents during production. The risks during operation of solar cells and electricity production from fossil fuels are small. Although the probability of accidents is small in well managed nuclear power production, the consequences may be immense. Used cadmium-containing solar cells are hazardous waste. However, as discussed below, the amount of cadmium is in the same order of magnitude as the amount in coal used for production of the same amount of electricity. Radioactive waste from nuclear power production is an even more serious problem, calling for deposition in deep rock. There are also safety aspects related to the link between nuclear power technology and nuclear weapon technology.

The main drawback of photovoltaics is that large scale use, above existing regulating capacity in the grid, requires new energy storage capacity. Technologies for this have not been fully developed, but it may he foreseen that they will involve burdens on the environment or risk of explosion if hydrogen is used as an energy carrier.

Large scale electricity generation in cadmium-containing solar cells is less problematic from an environmental point of view than are consumer products 
containing cadmium. The products are less widely distributed, which enables controlled treatment of used equipment. It may be recycled or deposited in a well controlled way.

Zweibel (1990) estimates that the cadmium content in coal used for electricity generation is of the same order of magnitude as the cadmium content in CdTe-cells producing the same amount of electricity $(1 \mathrm{~g} / \mathrm{MWh}$, provided $10 \%$ efficiency, 30 year lifetime and solar radiation intensity of approximately $1800 \mathrm{~W} / \mathrm{m}^{2}$ ). Replacing Swedish nuclear power ( $70 \mathrm{TWh} / \mathrm{year}$ ) with CdTe-cells would require about 100 tonnes of cadmium per year (provided 10\% efficiency, 30 year lifetime and solar radiation intensity of $1000 \mathrm{~W} / \mathrm{m}^{2}$ ). This is the same amount as the present Swedish use in NiCd-batteries (Government bill 1990). Action has been taken for recycling of these batteries. Recycling of large scale solar cell arrays is more feasible.

Scenarios with storage and use of hydrogen produced from solar cell electricity are far in the future and many technologies must be further developed before they become a reality. Several of the technologies that could be employed probably mean that the environment will be burdened in some way or other. In spite of these uncertainties, energy systems based on hydrogen from solar cell electricity are assessed as environmentally preferable to conventional energy systems. Hydrogen has advantages, especially as an alternative fuel for heavy road transports. The only harmful emission from hydrogen powered vehicles would be nitrogen oxide.

\section{ACKNOWLEDGEMENT}

Financial support from the Swedish Buildings Research Council is gratefully acknowledged.

\section{REFERENCES}

Carpetis, C. 1988. 'Storage, transport and distribution of hydrogen'. Chapter 9 in 'Hydrogen as an energy carrier. Technologies, systems, economy', Winter, C.-J. and J. Nitsch (eds). Springer Verlag, Berlin Heidelberg.

DOE 1989. 'Energy system emissions and material requirements'. Report prepared for the U.S. Department of Energy, Washington D.C. by Meridian Corporation, Alexandria, Virginia.

'Energifakta' 1991. In Swedish. (Facts about energy). AB Svensk energiförsörjning, Stockholm.

Engström, L. 1984. 'Solenergi för el- och bränsleproduktion', in Swedish. (Solar energy for electricity and fuel production). Energiforskningsnämnden Efn-rapport nr 8.

Fischer, M. and H. Eichert 1988. 'Safety aspects of hydrogen as energy carrier and energy storage'. Chapter 4 in 'Hydrogen as an energy carrier. Technologies, systems, economy', Winter, C.-J. and J. Nitsch (eds). Springer Verlag, Berlin Heidelberg. 
Garner, I.F. 1990. 'Amorphous silicon photovoltaics' . Proceedings of the 1st world renewable energy congress, Reading UK, 23-28 september 1990. Volume 1, pp 170. Edited by Sayigh A.A.M.

Government bill 1990. 'Hur mår Sverige? En rapport om miljösituationen', in Swedish. (How is Sweden? A report on the environmental situation). Bilaga A till regeringens proposition (appendix A to Government bill) 1990/91:90.

Hagedorn, G. 1989. 'Kumuliert Energieverbrauch und Erntefaktoren von Photovoltaik-Systemen', in German. (Cumulated energy use and energy pay-back of photovoltaic systems). Energiwirtschafteiche Tagesfragen, 1989 (11), 712-718.

Harte, J., Holdren, C., Scheider, R., and C. Shirley 1991. 'Toxics A to Z. A guide to everyday pollution hazards'. University of California Press, Berkely/Los Angeles/Oxford.

Hill, R. 1991. 'Polycrystalline solar cells' chapter 8 in 'Generating electricity from the sun'. Edited by Treble, F. C. Pergamon press.

Laveskog, A., Lindskog, A., and U. Stenberg. 1976. 'Om metaller', in Swedish. (About metals). Statens naturvårdsverk, Stockholm.

Lewis, R.J. 1992 'Sax's dangerous properties of industrial materials' Eighth edition. Van Nostrand Reinhold, New York.

Merian, E. 1990. 'Environmental chemistry and biological effects of cadmium compounds'. Toxicological and Environmental Chemistry 26, 27-44, 1990.

Morrison, G.M. 1994. 'Metal availability from the environment' in 'Handbook on metal-ligand interactions in biological fluids', Berthon, $G$ (ed), Volume 2. In press.

Moskowitz, P.D., Fthenakis V.M., Hamilton L.D., and Lee J.C. 1986-87. 'Public health issues in photovoltaic energy systems: an overview of concerns'. Solar cells 19 , 287-299, 1986-1987.

Moskowitz, P.D., and Fthenakis, V.M. 1990. 'Tox c materials released from photovoltaic modules during fires: health risks'. Solar cells 29, 63-71, 1990.

Moskowitz, P.D., and Fthenakis, V. M. 1991.'Environmental, health and safety issues associated with the manufacture and use of II-VI photovoltaic devices'. Solar cells $\mathbf{3 0}$, 89-99, 1991.

Palz, W. and Zibetta, H. 1991. 'Energy pay-back time of photovoltaic modules'. Int. J. Solar Energy 10, 211-216, 1991.

Peschka, W. 1988. 'Hydrogen energy applications engineering'. Chapter 2 in 'Hydrogen as an energy carrier. Technologies, systems, economy', Winter, C.-J. and J. Nitsch (eds). Springer Verlag, Berlin Heidelberg. 
Photovoltaic insider's report 1992, XI(2).

Robards, K., and Worsfold, P. 1991. 'Cadium: toxicology and analysis. A review'. Analyst 116, 549-568, 1991.

Sigurd, D. 1991. 'Solceller - den direkta vägen från ljus till el', in Swedish. (Solar cells - the direct path from light to electricity). Chapter 11 in Solsverige 1992, edited by Boysen, A. och Broman, L. Larssons förlag.

Sittig, M. 1991. 'Handbook of toxic and hazardous chemicals and carcinogens'. Noyes publications, Park Ridge.

Svensson, T. et. al. 1991. 'Environmental consequences of new energy technology. Solar heating, heat stores, heat pumps.' Swedish Council for Building Research D18:1991. Stockholm, Sweden.

Treble, F.C. 1991a 'Introduction' chapter 1 in 'Generating electricity from the sun'. Edited by Treble F.C. Pergamon Press.

Treble, F.C. 1991b. 'The crystalline silicon solar cell' chapter 3 in 'Generating electricity from the sun'. Edited by Treble F.C. Pergamon Press.

Treble, F.C. $1991 \mathrm{lc}$ 'Crystalline silicon photovoltaic modules' chapter 4 in 'Generating electricity from the sun'. Edited by Treble F.C. Pergamon Press.

Ullal, H.S., Zweibel, K., and T. Surek 1990. 'Recent technological advances in thin film solar cells'. Proceedings of the 1st World Renewable Energy Congress, Reading UK, 23-28 september 1990. Volume 1, pp 195. Edited by Sayigh A.A.M.

Zweibel, K. 1990. 'Harnessing solar power. The photovoltaic challenge'. Plenum Press. 